\title{
Implementasi Model Pembelajaran Jigsaw Dalam Upaya Meningkatkan Kemampuan Berpikir Kritis Dan Hasil Belajar Biologi Siswa Kelas XI
}

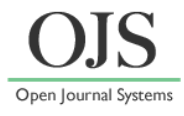

Tuharlan Efendi

Guru Biologi SMA Negeri 5 Rejang Lebong

*Email: tuharlanefendi@gmail.com

DOI: https://doi.org/10.33369/pendipa.4.1.12-16

\begin{abstract}
The aims of this study were to determine the improvement of critical thinking skills and biology learning outcomes of XI grade students of SMA Negeri 5 Rejang Lebong through the implementation of the Jigsaw learning model. Jigsaw learning model is a learning model that not only provides opportunities for students to develop cognitive abilities, but also develops social activities. This type of research conducted in this study is Classroom Action Research (CAR) or Classroom Action Research (CAR) with 2 Cycles. The subjects of this class action research were 19th grade students of Natural Sciences 2 with a total of 19 students. This subject selection is because based on the average grade of class, class XI IPA 2 has the lowest average value. The test instrument used consisted of tests of critical thinking skills and learning achievement tests. The results showed the average value of students' critical thinking skills in the first cycle was 67.78. In cycle II the average value of students' critical thinking skills was 84,706 . The average value of student learning outcomes in the first cycle is 66.4 with classical learning completeness is $30 \%$. In the second cycle was 82.7 with a classical learning completeness of $79.31 \%$. Based on student value data it is concluded that the implementation of the Jigsaw learning model can improve critical thinking skills and biology learning outcomes of students of class XI IPA 2 at SMA Negeri 5 Rejang Lebong.
\end{abstract}

Keywords: Jigsaw learning model, Critical Thinking Ability and Learning Outcomes

\begin{abstract}
ABSTRAK
Penelitian ini bertujuan untuk mengetahui peningkatan kemampuan berpikir kritis dan hasil belajar biologi Siswa kelas XI SMA Negeri 5 Rejang Lebong melalui implementasi model pembeljaran Jigsaw. Model pembelajaran jigsaw merupakan model pembelajaran yang tidak hanya memberikan kesempatan pada siswa untuk mengembangkan kemampuan kognitif, tetapi juga mengembangkan aktivitas sosialnya. Jenis penelitian yang dilakukan pada penelitian ini adalah Penelitian Tindakan Kelas (PTK) atau Classroom Action Research (CAR) dengan 2 Siklus. Subjek dari penelitian tindakan kelas ini adalah siswa kelas XI IPA 2 dengan jumlah 19 siswa. Pemilihan subjek ini dikarenakan berdasarkan nilai rata-rata kelas, kelas XI IPA 2 memiliki nilai rata-rata terendah. Instrumen tes yang digunakan terdiri dari tes kemampuan berpikir kritis dan tes hasil belajar. Hasil penelitian menunjukan Nilai rata-rata kemampuan berpikir kritis siswa pada siklus I adalah 67,78. Pada siklus II nilai rata-rata kemampuan berpikir kritis siswa adalah 84,706. Nilai rata-rata hasil belajar siswa pada siklus I adalah 66,4 dengan ketuntasan belajar klasikal adalah 30\%. Pada siklus II adalah 82,7 dengan ketuntasan belajar klasikal adalah 79,31\%. Berdasarkan data nilai siswa disimpulkan bahwa implementasi model pembelajaran Jigsaw dapat meningkatkan kemampuan berpikir kritis dan hasil belajar biologi siswa kelas XI IPA 2 pada SMA Negeri 5 Rejang Lebong.
\end{abstract}

Kata Kunci: Model pembelajaran Jigsaw, Kemampuan Berpikir Kritis dan Hasil Belajar 


\section{PENDAHULUAN}

Menurut Hamzah dan Muhlisrarini (2014) belajar adalah perubahan prilaku individu sebagai proses pengalaman baik yang dialami atau yang sengaja dirancang memerlukan penguatan untuk mendapatkan kemampuan, keterampilan, dan sikap secara bertahap dan berkelanjutan mulai dari masa bayi sampai masa tua melalui rangkaian proses belajar dengan keterlibatan dalam pendidikan formal (sekolah), informal (kursus), dan non formal (majelis-majelis ilmu).

Sekolah sebagai tempat proses belajar mempunyai kedudukan yang sangat penting dalam dunia pendidikan. Oleh karena itu pendidikan di sekolah memegang peranan penting dalam rangka mewujudkan tercapainya pendidikan nasional secara optimal seperti yang diharapkan. Proses belajar mengajar guru menjadi pemeran utama dalam menciptakan situasi interaktif yang edukatif, yakni interaksi antara guru dengan siswa, siswa dengan siswa dan sumber pembelajaran dalam menunjang tercapainya tujuan belajar.

Mata pelajaran Biologi di SMA merupakan perluasan dan pendalaman pelajaran IPA biologi di SMP yang bertujuan untuk mempelajari pola interaksi komponen-komponen yang ada di dalam bumi serta upaya manusia untuk mempertahankan keberadaannya di bumi. ujuan belajar biologi disekolah khususnya pada jenjang SMA adalah untuk mengetahui dan mempelajari kehidupan makhluk hidup yang berada di bumi.

Dalam proses pembelajaran masih banyak siswa yang kurang aktif dalam proses belajar mengajar, selain itu siswa juga tidak aktif dalam mencari materi sendiri yang selalu berpatokan pada buku panduan. Hal ini yang membuat guru harus mendominasi proses pembelajaran dengan metode ceramah, selalu memberikan materi dan penjelasan kepada siswa. Hal lain yang menjadi permasalahan yaitu masih banyak siswa yang kurang memperhatikan pelajaran, misalnya keluar masuk tanpa izin, cerita dan lain sebagainya, yang akan berdampak pada hasil belajar siswa.

Dalam proses pembelajaran, tentu banyak permasalahan yang dihadapi oleh para guru dan siswa. Sperti halnya uraian di atas, maka model pembelajaran Jigsaw sengaja diterapkan pada siswa kelas XI SMA Negeri 5 Rejang
Lebong. Hal ini diharapkan mampu meningkatkan hasil belajar siswa, peserta didik mampu berperan jauh lebih aktif dan menempati porsi yang lebih banyak dibandingkan guru, siswa juga mampu merumuskan suatu permasalahan dan mampu mengatasi permasalahan yang sedang dihadapi. Selain itu siswa juga mampu mengembangkan daya kreativitas yang mereka miliki.

Model pembelajaran jigsaw merupakan model pembelajaran yang tidak hanya memberikan kesempatan pada siswa untuk mengembangkan kemampuan kognitif, tetapi juga mengembangkan aktivitas sosialnya. Menurut Lie dalam Rusman (2014) menyatakan bahwa model pembelajaran jigsaw adalah sebuah model belajar kooperatif para ahli dengan cara siswa belajar dalam kelompok kecil yang terdiri dari atas empat sampai dengan enam orang siswa secara heterogen, dan siswa bekerjasama saling ketergantungan positif dan bertanggung jawab secara mandiri.

Adapun langkah-langkah model pembelajaran jigsaw menurut Rusman (2014), yaitu:

1. Siswa dikelompokkan dengan anggota \pm 4 orang

2. Tiap orang dalam tim diberi meteri dan tugas yang berbeda

3. Anggota dari tim yang berbeda dengan penugasan yang sama membentuk kelompok baru (kelompok ahli)

4. Setelah kelompok ahli berdiskusi, tiap anggota kembali ke kelompok asal dan menjelaskan kepada anggota kelompok tentang subbab yang mereka kuasai

5. Tiap tim ahli mempersentasikan hasil diskusi

6. Pembahasan

7. Penutup

Penggunaan metode Jigsaw diharapkan dapat meningkatkan hasil belajar siswa dalam mata pembelajaran Biologi. Adams (2013) dalam penggunaan metode jigsaw sebaiknya diperhatikan hal-hal berikut :

1. Setiap anggota dalam kelompok harus diberikan waktu yang cukup untuk menyumbangkan idenya.

2. Guru harus sadar waktu dan kreatif.

3. Setiap siswa harus diizinkan untuk beroperasi dengan kecepatannya sendiri.

4. Guru harus memberikan lebih banyak sumber informasi kepada siswa. 
5. Setiap siswa diizinkan untuk berpartisipasi sehingga, ada partisipasi aktif dari setiap siswa.

6. Jumlah siswa dalam kelompok harus diperhatikan untuk partisipasi yang efektif.

7. Semua siswa harus dilibatkan

8. Setiap anggota dalam kelompok harus diberi perubahan untuk berbicara dan berkontribusi selama presentasi.

9. Jumlah dalam setiap kelompok tidak boleh kurang lebih, setidaknya antara empat hingga enam anggota di masingmasing kelompok.

Menurut Dimyati dan Mudjiono (2006) menyatakan hasil belajar merupakan hasil dari suatu interaksi tindakan belajar dan tindakan mengajar. Adapun hasil belajar menurut Hamalik dalam Jihad dan Haris (2013) hasil belajar adalah pola-pola perbuatan, nilai-nilai, pengertianpengertian dan sikap-sikap, serta apersepsi dan abilitas. Dalam hal ini hasil belajar adalah sesuatu yang dicapai atau diperoleh siswa berkat adanya usaha atau pikiran yang dinyatakan dalam bentuk penguasaan, pengetahuan ataupun kecakapan dasar.

Berpikir kritis adalah sebuah proses sistematis yang memungkinkan siswa untuk merumuskan dan mengevaluasi keyakinan dan pendapat mereka sendiri. Berpikir kritis juga merupakan berpikir dengan baik, dan merenungkan tentang proses berpikir merupakan bagian dari berpikir dengan baik (Fitriawati, 2010). Aspek berpikir kritis ini dibutuhkan oleh siswa dalam pembeljaran Biologi untuk meningkatkan proses berpikir. Hal ini sejalan dengan pendapat Mahanal dkk (2016) menyatakan berpikir kritis membantu siswa dalam melihat dimana ha yang relevan dan tidak relevan dalam pembelajaran Biologi.

\section{METODE PENELITIAN}

Jenis penelitian yang dilakukan pada penelitian ini adalah Penelitian Tindakan Kelas (PTK) atau Classroom Action Research (CAR). Menurut Sanjaya (2013) PTK (penelitian tindak kelas) adalah proses pengkajian masalah pembelajaran di dalam kelas melalui refleksi diri dan upaya untuk memecahkannya dengan cara melakukan berbagai tindakan yang terancana dalam situasi nyata serta menganalisis setiap pengaruh dari tindakan tersebut. Penelitian ini dilaksanakan si SMA Negeri 5 Rejang Lebong yag beralamatkan di AirMerah, Curup Tengah. Adapun lama penelitian dimulai dari bulan Oktober sampai dengan November 2019. Subjek dari penelitian tindakan kelas ini adalah siswa kelas XI IPA 2 dengan jumlah 19 siswa. Pemilihan subjek ini dikarenakan berdasarkan nilai rata-rata kelas, kelas XI IPA2 memiliki nilai rata-rata terendah.

Prosedur atau langkah-langkah pelaksanaan penelitian tindakan kelas dapat dilihat pada Gambar 1.

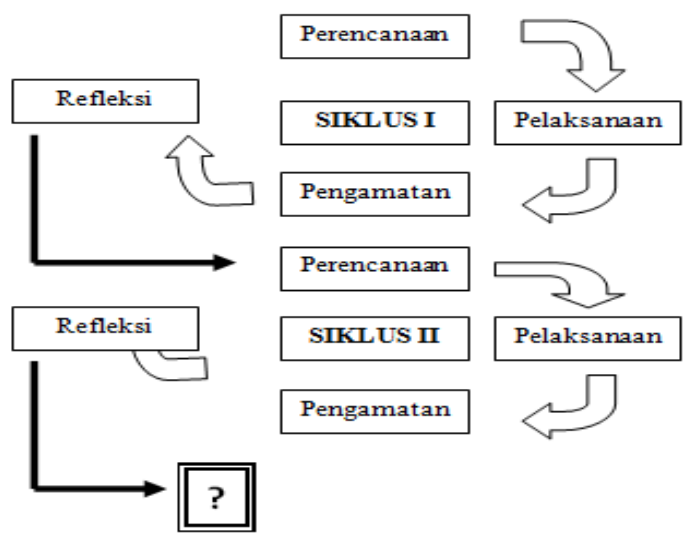

Gambar 1. Alur dalam Penelitian Tindakan Kelas (Arikunto,2010)

Pelaksanaan PTK dimulai dengan siklus pertama, dimana setiap siklusnya terdiri atas perencanaan, pelaksanaan, pengamatan, dan refleksi. Keberhasilan PTK diketahui dari keberhasilan dan hambatan dari tindakan yang dilaksanakan pada siklus pertama, selanjutnya guru rancangan untuk siklus kedua. Apabila siklus kedua telah selesai dan hasilnya sudah sesuai dengan yang diharapkan, maka siklus dihentikan. Instrumen yang digunakan untuk penelitian ini terdiri atas Tes kemampuan berpikir kritis dan Tes Hasil Belajar.

\section{HASIL DAN PEMBAHASAN Kemampuan Berpikir Kritis}

Penelitian ini bertujuan untuk mengetahui cara menerapkan pembelajaran Jigsaw agar dapat meningkatkan Berpikir Kritis siswa Kelas XI SMA N 5 Rejang Lebong. Hasil Penelitian Menunjukan peningkatan kemampuan berpikir kritis siswa meningkat pada setiap siklus. Nilai rata-rata siswa pada siklus I adalah 67,78 adapun jumlah siswa yang memperoleh nilai $\geq 80$ adalah 
1. Karena, nilai rata-rata siswa pada siklus $\mathrm{I} \leq 80$ maka, pembelajaran belum tercapai. Pada siklus II nilai rata-rata siswa adalah 84,706 adapun jumlah siswa yang memperoleh nilai $\geq 80$ adalah 11 . Sehingga pada siklus II pembelajaran tercapai karena telah sesuai dengan indikator kerberhasilan

Berdasarkan Pengolahan data, diketahui bahwa kemampuan berpikir kritis siswa pada pokok bahasan Sistem Gerak Pada Manusia pada siklus I berada pada kategori Kurang. Pada siklus II kemampuan berpikir Kritis meningkat menjadi Baik kemudian disusul oleh kemampuan berpikir kritis dengan kategori kurang dan cukup. RataRata yang diperoleh siswa pada siklus I adalah sebesar 67,22. Nilai maksimal yang diperoleh siswa adalah 93 dan nilai minimal siswa adalah 62. Kondisi ini mengalami peningkatan di Siklus II dimana, Nilai rata-rata menjadi 86,112. Perolehan nilai tersebut menunjukan bahwa peningkatan kemampuan berpikir kritis siswa meningkat cukup tinggi.

Berdasarkan aspek indikator kemampuan berpikir kritis yang terdiri atas Elementary Clarification, Keterampilan mengenal dan memecahkan masalah dan Inference mengalami peningkatan dari siklus sebelumnya, data disajikan pada tabel 1 .

Tabel 1. Kemampuan Berpikir Kriris Siswa

\begin{tabular}{|c|c|c|c|c|}
\hline $\begin{array}{c}\text { Aspek } \\
\text { kemampuan } \\
\text { berpikir kritis }\end{array}$ & $\begin{array}{c}\text { Rata- } \\
\text { Rata } \\
\text { Siklus I }\end{array}$ & Kategori & $\begin{array}{c}\text { Rata- } \\
\text { Rata } \\
\text { Siklus II }\end{array}$ & Kategori \\
\hline $\begin{array}{c}\text { Elementary } \\
\text { Calrification }\end{array}$ & 65,42 & Cukup & 80,15 & Baik \\
\hline $\begin{array}{c}\text { Keterampilan } \\
\text { mengenal } \\
\text { dan } \\
\text { memecahkan } \\
\text { masalah }\end{array}$ & 70,12 & Baik & 83,48 & Baik \\
\hline Inference & 65,27 & Cukup & 70,65 & Baik \\
\hline
\end{tabular}

Persentase kemampuan Elementary Clarification yang ditunjukan dengan menulis diketahui maupun yang ditanyakan soal dengan tepat dalam kategori Cukup pada siklus I dengan nilai 65,42 dan mengalami peningkatan menjadi kategori baik pada siklus II dengan rata-rata 80,15 . Hal ini disebabkan siswa mulai terbiasa belajar menggunakan pembeljaran Jigsaw. Pola pengerjaan model jigsaw dalam kategori kelompok ahli juga melatih siswa untuk menelaah apa yang diketahui soal baru mencari jawaban soal.

\section{Hasil Belajar}

Perkembangan nilai siswa secara individu tidak selalu meningkat disetiap siklusnya. Nilai siswa yang meningkat disetiap siklusnya ada 11 orang siswa sedangkan 8 lainnya mengalami perubahan nilai naik turun dari siklus I sampai siklus II. Pada siklus II ada 4 orang siswa yang mengalami penurunan. Berdasarkan perkembangan hasil tes pada siklus I terdapat 7 siswa yang belum mencapai kriteria ketuntasan minimal. Pada siklus kedua ada 4 orang siswa yang belum mencapai kriteria ketuntasan.

Penerapan model pembelajaran jigsaw dapat meningkatkan hasil belajar Biologi siswa di SMA Negeri 5 Rejang Lebong dengan cara:

a. Siswa melakukan kegiatan membaca materi yang diperoleh pada saat diskusi kelompok ahli.

b. Siswa diberikan tanggung jawab untuk mengeluarkan pendapat tentang materi yang diperoleh dalam kelompok ahli

c. Siswa diberikan kerjasama dalam mengerjakan materi yang belum dipahami kepada anggota kelompok ahli lain dalam diskusi kelompok awal

Nilai rata-rata hasil belajar siswa pada siklus I adalah 66,4 dengan ketuntasan belajar klasikal adalah $30 \%$. Pada siklus II adalah 82,7 dengan ketuntasan belajar klasikal adalah $79,31 \%$. Berdasarkan hasil belajar siswa dalam pembelajaran biologi dapat dilihat terjadi peningkatan dalam setiap siklus. Hal ini didukung oleh pendapat Bialangi dkk (2016) menyatakan model Jigsaw memungkinkan kemampuan siswa yang akademik rendah untuk mencapai hasil pembelajaran sama dengan kemampuan siswa akademik tinggi.

\section{KESIMPULAN}

Berdasarkan hasil penelitian yang dilakukan maka dapat disimpulkan bahwa hasil dari Implementasi model pembelajaran Jigsaw dapat meningkatkan kemampuan berpikir kritis dan hasil belajar biologi siswa kelas XI IPA 2 pada SMA Negeri 5 Rejang Lebong. Nilai rata-rata kemampuan berpikir kritis siswa pada siklus I adalah 67,78. Pada siklus II nilai rata-rata kemampuan berpikir kritis siswa adalah 84,706. Nilai rata-rata hasil belajar siswa pada siklus I 
adalah 66,4 dengan ketuntasan belajar klasikal adalah $30 \%$. Pada siklus II adalah 82,7 dengan ketuntasan belajar klasikal adalah 79,31\%.

\section{UCAPAN TERIMA KASIH}

Peneliti secara khusus mengucapkan terima kasih yang sebesar-besarnya kepada Kepala sekolah dan seluruh guru serta staf SMA Negeri 5 Rejang Lebong atas diizinkannya melaksanakan kegiatan penelitian ini.

\section{DAFTAR PUSTAKA}

Adams, Francis Hull, (2013). Using Jigsaw Technique As An Effective Way Of Promoting Cooperative Learning Among Primary Six Pupils In Fijai. International Journal of Education and Practice, 1(6):64-74.

Arikunto, Suharsimi. (2010). Prosedur Penelitian Suatu Pendekatan Praktik. Jakarta : PT Rineka Cipta.

Bialangi, Mursito S., Zubaidah, Siti.,Amin, Mohamad.,Gofur, Abdul. (2016). Improving The Biology Learning Result Of Low Academic Ability Student by using Jigsaw and Guided Inquiry Learning. International Journal of Research \& Review. Vol 3, issue 11, November 2016.
Hamzah, A., \& Muhlisrarini. (2014). Perencanaan Dan Strategi Pembelajaran Matematika. Jakarta: RajaGrafindo Persada.

Rusman. (2014). Model-Model Pembelajaran Mengembangkan Profesionalisme Guru. Jakarta: RajaGrafindo Persada.

Dimyati, \& Mudjiono. (2006). Belajar Dan Pembelajaran. Jakarta: Rineka Cipta.

Jihad, A., \& Haris, A. (2013). Evaluasi Pembelajaran. Yogyakarta: Multi Presindo.

Fitriawati, Nina. (2010) Penerapan model Pembelajran Berbasis Masalah (Problem Based Learning) Dalam Meningkatkan Kemampuan Berpikir Kritis Siswa Pada Mata Pelajaran IPS Terpadu Kelas VIII Di MTsN Selorejo Blitar,.UIN Maulana Malik Ibrahim Malang.

Mahanal, Susriyati., Zubaidah, Siti., Bahri, Arsad.(2016) Improving students' critical thinking skills through Remap NHT in biology classroom. Asia-Pacific Forum on Science Learning and Teaching, 17(2), 11, p.4.

Sanjaya, Wina. (2006). Strategi Pembelajaran Berorientasi Standar Proses Pendidikan. Jakarta: Kencana. 